\title{
Impact of Foreign Direct Investment on Sectoral Performance in the Nigerian Economy: A Study of Telecommunications Sector
}

\section{Ezeanyeji Clement I. Ph.D}

Department of Economics, Faculty of Social

Sciences, Chukwuemeka Odumegwu Ojukwu

University, Anambra State, Nigeria

drsundayeze@gmail.com
Ifebi Ogonna Lord'nuel

Department of Economics, Faculty of Social

Sciences, Chukwuemeka Odumegwu Ojukwu

University, Anambra State

Nigeria

\begin{abstract}
This research work studied the Impact of Foreign Direct Investment on Sectoral Performance in the Nigerian Economy with special reference to the Telecommunications Sector. It focuses on the role played by Foreign Direct Investment (FDI) in the development of the Telecommunications sector of Nigeria. The Ordinary Least Square (OLS) econometric method was used to examine the regression model that was stated to examine the role Foreign Direct Investment has played in the performance of the Nigerian Telecommunications Sector. The results of the empirical analysis showed that Foreign Direct Investment has contributed significantly to the performance of the Telecommunications Sector in terms of its contribution to the Gross Domestic Product of Nigeria. Some of the recommendations made in the research project are that: the government should initiate policies that will promote the long-run growth of the Telecommunications sector and the economy at large; infrastructural facilities such as power supply should be efficiently provided; government should focus on maintaining political stability which should serve as key to sustainable growth and development of the telecommunications sector of the Nigerian economy etc.
\end{abstract}

Keywords: Foreign direct investment, telecommunications sector, sectoral performance, gross domestic product, error correction model.

\section{INTRODUCTION}

The need for foreign capital to supplement domestic resources is being felt by the developing economies, in view of growing mismatch between their domestic capital stock and capital requirements. This is evidenced in the new attention being given to the drive for foreign capital especially in developing economies. Fosu and Magnus (2006) and Omisakin, et al. (2009) pointed out rightly that foreign capital inflow is an important vehicle for augmenting the supply of funds for domestic investment. Ngowi (2001) also argued that African countries and other developing countries need substantial inflow of foreign capital to fill the saving and foreign exchange gaps associated with a rapid rate of capital accumulation and growth needed to overcome the widespread poverty in these countries. Besides, developing countries are preferred to developed countries by foreign investors because of the higher rate of return on investment in these countries (Ghose, 2004; Knill, 2005, Vita and Kyaw, 2008). However, whether the foreign investors are willing to take advantage of this high rate of return in the face of high production cost and distorted investment incentives is another issue entirely.

The relative advantage(s) of Foreign Direct Investment (FDI) as a productivity-enhancing package is now widely acknowledged in the literature. Fosu and Magnus (2006) stressed that foreign capital investment can stimulate local investment by increasing domestic investment through links in the production chain. Ghose (2004) noted that foreign direct investment contributes to economic growth in developing countries through two channels; one of which is externalities in the form of positive productivity spillovers to domestic enterprises. Dauda (2007) also noted that foreign capital investment increases the Gross Domestic Product and generates a stream of real incomes in the host country, which consequently expands employment, raises wages and salaries, lower commodity prices, increase tax revenue accruable to the government. Alfaroa, et al., (2004) found that although foreign direct investment alone plays an ambiguous role in contributing to economic growth, countries with a well-developed financial markets gain significantly more from it.

Despite the aforementioned benefits of foreign direct investment in the host country, a number of authors have argued against it in the literature. For instance, Busse and Hefeker (2005) argued that 
foreign investments run the risk of sudden reversal if the economic environment or the perception of investors change, giving rise to financial and economic crises. Alfaro and Chanda (2003) argued that the potentials of foreign capital investment could be severely impeded if there is absence of welldeveloped financial markets, which is widely the case in African countries. Adam (2002) hinted that foreign direct investment that exhibits market seeking motivations might create distortions in the host economy through monopolies and high barriers of entry. UNCTAD (2005) observed that foreign investment in Africa has advanced much further and faster than integration internally, especially in structural, institutional and policy trends, and in some cases at its expense.

The acknowledged benefits of the foreign direct investment seems to be more than the demerits, and this seems to explain the current move of developing countries including Nigeria, seeking to attract private foreign direct investments by removing the structural barriers and encouraging foreign investors. Such encouragement includes offers of incentives such as income tax holidays, import duties exemptions, and subsidies to foreign firms. In an apparent shift of long-held stance against foreign direct investment, the Nigerian government, like other developing nations introduced the Structural Adjustment Programme (SAP) comprising a package of economic policy measures in 1986. To reinforce the gains of the economic policy measures and further encourage foreign participation in the economy, the Nigerian Investment Promotion Decree was promulgated in 1995 to encourage, promote and coordinate foreign investment and enhance capacity utilisation in the productive sector of the economy. It also provides an opportunity for foreign participation in Nigerian enterprises up to 100 percent ownership. However, the full deregulation of the telecommunication sector was not implemented until 2001.

\subsection{Statement of the Problem}

Over the years, successive Nigerian governments have viewed foreign direct investment as a vehicle for political and economic domination of Nigeria and hence the thrust of government policy (indigenisation policy) through the Nigeria Enterprise Promotion Decree (NEPD) has been to regulate foreign direct investment, with a maximum of $40 \%$ foreign participation allowed. This has resulted in a decline in both private and foreign investment and has therefore slowed down growth in all sectors of the economy including the telecommunications sector. This has consequently reduced long-run levels of per capita consumption and income. The trend had been attributed to the debt crisis and global shocks which affected the country in the 1980s, and which has set off a protracted period of macroeconomic instability with an eventual drop in external financing. This therefore, discouraged foreign participation in the economy as foreign direct investment formed only a small percentage of the nation's gross domestic product (GDP) though marginally rising from $-0.80 \%$ in 1980 , to $1.80 \%$ in 1990. In an attempt to create a suitable climate for investment and growth within the economy, and to stimulate her economic recovery efforts from a prolonged and severe recession, the Nigerian Government introduced the Structural Adjustment Programme (SAP) comprising a package of economic policy measures in July 1986.

The programme incorporates trade and exchange reforms reinforced by monetary and fiscal measures, which are geared towards diversifying the mono export base by stimulating domestic production and discouraging use of improved inputs for local production. The supply side of the package seeks to enhance aggregate output with special emphasis on agro/agro-allied and manufacturing sectors for which specific policy measures were designed. The implementation of SAP was expected to bring about some improvements in the economy. For instance, the sharp exchange rate depreciation was expected to discourage importation and make multinationals that have profited through export trade (from the former over-valuation of the Naira) to prefer investment in the domestic economy if they were to maintain their established trade links. But all these were not achieved due to improper implementation of the programme.

\subsection{Objectives of the Study}

The main objective of this research is to examine the impact of foreign direct investment on sectoral performance in the Nigerian economy with special reference to the Telecommunications Sector. Specifically, the research intends to find out the following:

i. The trend of foreign direct investment in Nigeria's Telecommunication sector;

ii. To find suitable strategies that would stimulate foreign direct investment into the telecommunications sector of the Nigerian economy.

iii. To identify the determinants of foreign direct investment in Nigeria. 


\subsection{Research Hypothesis}

The research hypothesis that would be tested in the course of this study is stated below:

$\mathbf{H}_{\mathbf{0}}$ : There is no positive relationship between foreign direct investment and the performance of the telecommunications sector in Nigeria.

$\mathbf{H}_{1}$ : There is a positive relationship between foreign direct investment and the performance of the telecommunications sector in Nigeria.

\section{LITERATURE REVIEW}

\subsection{Theoretical Review}

Several economic theories attempted to evaluate the role of FDI in the country both from positive and negative point of view. Economic theories like neo-classical theory, dependency theory, and endogenous growth model theory are going to be considered as basic points of discussion. Neoclassical perspective is based on a basic principle in economics, which suggests that economic growth requires capital investment in the form of long-term commitment (Adams, 2009). It simply means that this theory creates a better relationship between the FDI and economy development of every society, most in particular, developing countries.

The second theory to be considered is dependency theory; According to Aremu (2005), dependency theory maintains that, the poorness of developing countries is due to: imperial neglect; overdependence upon primary products as exports to developed countries; foreign investors" malpractices, particularly through transfer of price mechanism; foreign firm control of key economic sectors with crowding-out effect of domestic firms; implantation of inappropriate technology in developing countries; introduction of international division of labour to the disadvantage of developing counties; prevention of independent development strategy fashioned around domestic technology and indigenous investors; distortion of the domestic labour force through discriminatory remuneration; and reliance on foreign capital in form of aid that usually aggravated corruption.

Furthermore, the dependency theorists also focused on the several ways by which, FDI of multinational corporations distort developing nation's economy. Some scholars of this theory believed that, distortive factors include the crowding out of national firms, rising unemployment related to the use of capital-intensive technology, and a marked loss of political sovereignty (Umah, 2007). It has also been argued that FDI are more exploitative and imperialistic in nature, thus ensuring that the host country absolutely depends on the home country and her capital (Anyanwu, 1993). This theory from its points of analysis could be discovered that it creates negative relationship between FDI and economic growth of the developing countries. The theory is of great belief that the economic involvement of developed countries into developing nations under multinational companies and FDI will surely resort to economic disadvantages of developing nations.

The last theory to be considered is endogenous growth models theory; while neoclassical theory assumes the notion that long term investment is a great determinant of the economic growth of the country, endogenous growth model theory explained that physical investment is not a measure of economic growth of a country but the effectiveness and efficiency in the use of these investments. Economic models of endogenous growth have been applied to examine the effects of FDI on economic growth through the diffusion of technology (Barro, 1991). Romer (1990) argues that FDI propels economic growth through strengthening human capital, the most essential factor in $R \& D$ effort; while Grossman and Helpman (1991) emphasize that an increase in competition and innovation will result in technological progress and increase productivity and, thus, promote economic growth in the long run. From the analyses made under this theory, it can be discovered that the theory suggests a better relationship between the FDI and economic growth of the developing countries.

\subsection{Benefits of Foreign Direct Investment}

Over the past two decades, FDI has been one of the most important driving forces for the world's economic growth. According to the US Department of Commerce, FDI is a direct investment which "implies that a person in one country has a lasting interest in and a degree of influence over the management of, a business enterprise in another country." The US Commerce Department defines FDI as "ownership or control by a foreign person of 10 percent or more of an enterprise's voting 
securities or the equivalent," which is deemed enough to influence management decisions. At a Global Investment Forum hosted by the United Nations Conference on Trade and Development (UNCTAD), it was reported that "there was a strong feeling among ministers from some developing countries that more research and analysis was needed about the critical issues at stake in a multilateral framework on investment...and many speakers stressed the complexity of the issues related to the effects of economic policy liberalization on the quantity, quality and distribution of FDI, and its impact on development."

Requiring sufficient economic information and abundant funds, foreign investment is always accompanied by higher risks. With such risks, foreign investment also comes with the possibility of much greater returns. Traditionally, foreign direct investment has been very closely related either with trade or with an international development agency. Most current foreign investment thus has either been the result of someone taking a huge risk or the result of an international organization such as the World Bank underwriting that risk. Meanwhile, international developmental agencies often pursue the more enlightened goal of helping countries develop properly rather than seeking the greatest return.

The benefits of foreign direct investment include promoting economic growth, technology transfer and job-creation in the local economies. It is assumed that exports would increase since a large part of exports is comprised of shipments from domestic companies to their foreign affiliates. Technology transfer from foreign investment projects will improve the efficiency of local firms as well. These effects become the major attractions for developing and underdeveloped countries seeking foreign direct investment. In addition, FDI can serve to integrate domestic markets into the global economic system far more effectively than could have been achieved only by traditional trade flows. The benefits from FDI will be enhanced in an open investment environment with a democratic trade and investment regime, active competition policies, macroeconomic stability and privatization and deregulation. Under such conditions, FDI can play a key role in improving the capacity of a country to correspond to global economic integration and future national developmental strategies.

In practice, the greater the openness and freedom toward FDI, the more economic reforms and potential benefits that receiving countries will reap. Although FDI implicitly brings large economic benefits and potentially attracts numerous business opportunities, many countries are only partially open to foreign investment or even refuse business with foreign enterprises. Those countries believe they will be losing the control power over the local economy by inviting foreign investment.

They often use performance requirements such as exporting requirements or technology transfer agreements to control the categories and sizes of FDI. For many countries, performance requirements on foreign investment were considered necessary and desirable to ensure that the activities of foreign capitals are consonant with local countries' developmental strategies (Thompson, 1999). The same decline in effectiveness can be seen in terms of policies designed to maximize the potential benefits from inward investment. However, since it has been acknowledged that FDI can stimulate economic growth and national development, there remains a tremendous diversity in countries' approaches on their policies towards FDI. Countries can also screen incoming investment and retain control on foreign participation in particular sectors. Those measures are designed to certify local government can still retain the final decision on economic policies and ensure foreign investment will not cause negative effects on national development.

\subsection{Determinants of Foreign Direct Investment}

This section focuses on a review of foreign direct investment determinants. These are the factors that determine foreign direct investment inflows into a given geographical location, say, a country or a region. They give investors the confidence needed to invest in foreign markets. The list of these determinants may be very long, but not all determinants are equally important to every investor in every location at all times. Some determinants may be more important to a given investor in a given location at a given time than to another investor. A given determinant may be a necessary and satisfactory factor by itself for foreign direct investment inflow in one location but not in another. For the most part, they form a complementary set. What interests us in this section is to find out the factors that would motivate or attract a multinational enterprise (MNE) to invest in a particular destination after making the decision to go multinational. These are the factors that give the investors the confidence to commit their normally massive, expensive and scarce resources in a given foreign destination. 
It is difficult to determine the exact quantity and quality of foreign direct investment determinants that should be present in a location for it to attract a given level of foreign direct investment inflows. What is clear is that every location must possess a certain critical minimum of these determinants before foreign direct investment inflows begin to take place.

UNCTAD's 1998 World Investment Report presents some host country determinants of foreign direct investment. These include:

\section{Policy Framework for Foreign Direct Investment:}

i. Economic, political and social stability.

ii. Rules regulating entry and operations (of foreign direct investments).

iii. Standard of treatment of foreign affiliates.

iv. Policies on functioning and structure of the markets.

v. International agreement on foreign direct investment.

vi. Privatization policy.

vii. Trade policy (tariffs and non-tariff barriers and coherence of foreign direct investment and trade policy.

viii. Tax policy.

\section{Economic Determinants:}

i. Business facilitation.

ii. Investment promotion (including image-building and investment-generating activities and investment - facilitating services).

iii. Investment incentives.

iv. Hassle costs (related to corruption and administrative efficiency).

v. Social amenities (for example bilingual schools, quality of life.

vi. After-investment services.

UNCTAD (1998) lists the principal economic determinants in host countries. It matches types of foreign direct investment by motives of the firms with those principal economic determinants. Where we have a market-seeking type of foreign direct investment, it looks for criteria concerning market size and per capita income; market growth; access to regional and global markets; country-specific consumer preferences and; structure of markets. In the case of foreign direct investment of a resource/asset- seeking type, the focus would turn on raw materials, low-cost unskilled labour as well as skilled labour, technological, innovative and other created assets (like brand names), and physical infrastructure (ports, roads, power, telecommunications).

There is another type of foreign direct investment: one that is directed at ensuring efficiency. This type looks for favorable balances in the costs of resources and assets listed above, adjusted for labour productivity as well as in other input costs, such as transport and communications costs to/from and within the host economy. Finally, it is interested in whether or not the host economy is part of a regional integration agreement that may be conducive to the establishment of regional corporate networks.

Given that foreign direct investment is increasingly geared to technologically intensive activities, technological assets are becoming more and more important for Trade Nation Cooperation's (TNCs) to maintain and enhance their competitiveness. A destination's possession of a strong indigenous technology base is vital for attracting high-technology foreign direct investment and for research and development (R\&D) investments by TNCs. A would-be host country, in order to attract scarce foreign direct investment, must be able to provide the requisite inputs for modern production systems. For example, efficiency-seeking foreign direct investment will tend to be located in those destinations that are able to supply a skilled and disciplined workforce and good technical and physical infrastructure. Bjorvatn (1999) says that firms will locate their industrial activities in countries with superior quality of national infrastructure. A good quantity and quality of infrastructure in a location is among the factors that facilitate business operations. Physical infrastructure includes roads, railways, ports and telecommunications facilities. The latter include traditional postal services and modern communication facilities such as the network Internet. 
Regional Trading Blocks (RTBs) are essential determinants of foreign direct investment. These represent various forms of economic integration among countries. They are designed to promote cross-or inter- country trade and mobility of factor services from within member countries by fostering a more market-oriented pattern of intra-regional resource allocation. They have the potential to increase the size of a unified market. Common external tariffs imposed by RTBs are likely to force non- members to enter the market through foreign direct investment rather than through trade. This is one of the ways in which RTBs may be among the essential foreign direct investment determinants. No wonder then that the European Union as a group attracts so much foreign direct investment. The importance of regional groupings as a factor in attracting foreign direct investment has also been advocated by the UNCTAD. The organization argues that countries stand to reap some economies of scale in regional groupings and that it develops complimentarily of interests between land-locked and coastal countries. In the African context, such economic groupings as the Economic Community of West African States (ECOWAS) and the Southern African Development Corporation (SADC) may be Language and business culture are also determinants of foreign direct investment inflows. In a destination where a language like English is commonly spoken by the majority of the population, one would expect more foreign direct investment inflows than if the case were otherwise. Of course, we have cases where there has been more foreign direct investment inflow to destinations where language is, on the surface, a barrier, e.g., South Korea, Indonesia, Taiwan and China than to where language seems to be an advantage as in most African countries like Nigeria where English is widely spoken.

Tax exemptions, tax holidays or tax reduction for foreign investors, and similar incentives would play a positive role in attracting foreign direct investments into a given destination. Some other types of incentives that may play similar roles include guarantees against arbitrary treatment in case of nationalization; government provision of such utilities as water, power and communication at subsidized prices or free of cost; tariffs or quotas set for competing imports; reductions/elimination of import duties on inputs; interest rate subsidies; guarantees for loans and coverage for exchange rate risks; wage subsidies; training grants and relaxation of legal obligation towards employees. But the costs of these incentives to the host economy must be compared to the potential benefits that foreign direct investment may bring.

Labour availability and relatively low labour costs, high skills and efficiency are important factors determining foreign direct investment inflow into a given destination. For example, the region covered by the fifteen former communist states of Central and Eastern Europe is seen by some MNEs such as Daewoo, as a low-cost production base that can be used as an export platform to service West European markets. Relatively lower wage costs have also been used to account for increased foreign direct investments in Asia especially in the Tigers of Asia. The labour force has to be non- militant. There should be generally good labour relation, low rate of industrial disputes, strikes and lockouts and a high level of employee loyalty in a given destination for foreign direct investments to flow there in a substantial amount.

Investors may also be attracted by other factors such as low cost but high quality inputs and minimal transaction costs in their interaction with the government and other bureaucracies. The extent to which unnecessary, distorting and wasteful business costs are reduced will most likely contribute positively to foreign direct investment inflow into a given destination. The strength of a currency also may determine foreign direct investment inflow. A relatively weak currency would be more likely to attract foreign direct investments than a relatively strong one. Realizing potential losses inherent in converting weak currency to hard ones, many foreign investors may simply plow back into the host economy their profits and other remittances. Currency devaluation may lead to cheap assets. Cheap assets, on the other hand, are expected to attract more foreign direct investments especially through Mergers and Acquisitions (M\&As).

Economic and structural reforms in a country are very important in winning foreign investors' confidence to take their investment funds there. Such reforms can be very wide and far-reaching. The various reform measures may overlap with each other. Reforms, whether social, political or economic, should aim at creating, maintaining and/or improving the environment for business, both local and foreign. Some of the important reforms can involve the relaxation of entry restrictions in various sectors, deregulation in various industries, abolition of price controls, easing of controls over mergers and acquisitions and trade practices, removal of government monopoly, privatization, independence of the Central Bank, and elimination of import licensing, removal of foreign-exchange - rate and interest rate controls. Such reforms are likely to create a business-friendly environment that is likely 
to attract more foreign direct investment. But the reforms may be expensive to a nation and its people. For these reforms to be justified, they must take into consideration the impact on the populace of the country concerned.

Investors are more likely to choose those locations that make it easier to do business. These are likely to be found in countries with solid economic fundamentals. The 1997 figure for developed countries' share of global foreign direct investment inflow (72\%) most likely reflects the presence of the solid economic fundamentals in the United States and some European countries. It has been argued that the attractiveness of developing countries for foreign capital depends on the capabilities of these countries to apply existing technologies and not on their role in producing new one. That is, foreign direct investment inflow to such countries in the first place will depend on, among other things, the existence of this capability. We may then list the ability to use the existing technology as yet another factor that can determine foreign direct investment inflow into a specific destination.

Non-discriminatory treatment of investors, consistency and predictability in government policies are also among the foreign direct investment determinants. Investors need to be in a position where they can plan their activities efficiently within the policy environment of the government. Those government policies that directly or indirectly affect investments should be reliable, accessible, up to date and widely publicized. Government credibility is essential if more foreign direct investment is to flow to a destination. In this connection, the system of processing and approving new investments may be a crucial determinant for further foreign direct investment inflow into the same destination. A long bureaucratic, non- transparent and corrupt process is likely to scare away potential investors. What is needed is a relatively short, transparent and non-corrupt process undertaken in, if possible, a one-stop-shop. Some other foreign direct investment determinants include a positive economic growth in a given destination.

Economic growth in turn determines market prospects. It is more likely that foreign direct investment will flow more to destinations with promising economic growth both in the short and long run. Other foreign direct investment determinants mentioned in the literature include low indirect social costs like bribery or its absence; availability of risk capital; synergy between public and private research and development programs; low rate or absence of criminality, alcohol and narcotic abuse as these affect the security of personnel and the quality of the labour force as a whole. The values, norms and culture of the population in the host economy must be ready to support the principle of free competition. Authorities must be able to adjust policy to reflect new economic, social and political realities of the time. Prevailing views on environmental issues and the occurrence of activism, while important, must not be fanatical and detrimental to business operation. They must be reasonable. Countries' health services, recreation possibilities and overall quality of life, too, influence foreign direct investment inflow.

The presence of investment opportunities in a country, needless to say, is another important foreign direct investment determinant. The opportunities should be made known to potential investors through effective promotion, which includes marketing a country and coordinating the supply of a country's immobile assets with the specific needs of targeted investors. One cannot always expect that investors will take the trouble of finding out the available opportunities in every country. Countries must reach out to investors. Where the world's largest TNCs invest is sometimes determined by access to technology and innovative capacity in particular countries. These factors, in contrast to natural resources, are called "created assets". These include communication infrastructure marketing networks, knowledge - which can be used as a proxy for skills, attitudes to wealth creation and business culture, technological, managerial and innovative capabilities, competence at organizing income-generating assets productively, as well as relationships (such as between firms and contracts with governments) and the stock of information, and, finally, trade marks or goodwill. Possessing the assets just adumbrated is critical for competitiveness in a liberalizing and globalizing world economy.

However, the traditional factors such as access to markets, natural and other resources like low-cost labour are still key foreign direct investment determinants especially for many firms that have not yet developed large-scale international operations. As mentioned at the beginning of this section one can see that some of the determinants overlap. It is almost impossible to give a threshold of the determinants that should exist in a location before a given amount of foreign direct investment begins to flow there. But it is clear that a certain critical minimum of the determinants should exist before the 
inflows start to take place. A location that possesses an optimal quantity and quality of the determinants can be said to be an attractive destination for foreign direct investment. For a destination to attract or increase its foreign direct investment share, it should possess this critical minimum of the determinants.

\subsection{Factors Affecting the amount of Foreign Direct Investment}

Nigeria as a nation has some of inherent features, which made the nation unique in Africa as a continent and in the world in general. The nation is blessed with enough natural resources to survive on its own sufficiently but is still in battle of development up till tomorrow. There are numerous challenges militating against the positive development of the nation, which could actually hinder the nation to survive in some other aspects like attracting the foreign investors to come into the country. The tremendous advantages of FDI to the economic growth of the developing countries have made it official for every nation to try her best by making themselves an attractive ground for the foreign investors to come into their nations. In fact some finding made it known that Pakistan's ability to develop is dependent upon the country's effective capacity to attract the foreign investors. It is however, important to discuss some inherent factors in developing countries, which could actually affect the smooth inflow of FDI in the continent.

1. Political Instability: One of the major characteristics of African nations is incessant changing of government, which usually come up as a result military intervention in government, ethnic crisis, and frequent occurrence of war. According to Rogoff and Reinhart (2003) in their investigation about how susceptible the region is to the occurrence of war within the year 1960-2001, had their result based on the fact that the regional susceptibility to war index is $26.3 \%$ for Africa compared to $19.4 \%$ and $9.9 \%$ for Asia and the Western Hemisphere, respectively. The study also made it known that there is a statistically significant negative correlation between FDI and conflicts in Africa. This emphasizes on the fact that, intervention of foreign businesses in the continent has no relationship with the causes of war in the region. Political instability will surely hinder the inflow of FDI in African countries.

2. Lack of Policy Transparency: The fact that political instability is one of the inherent features of the continent precipitates that incessant changing of government will also lead to incessant changing of policies. This automatically makes it difficult to actually predict what the policies of governments are all about in African countries. The policy of increment in transaction cost, tax, and rules and regulations would not be easy to measure by the foreign investors and this will make the continent so risky for them to invest their businesses.

3. Unstable Macro-economic Variable: Effective presence of macroeconomic variable is one of the basic determinants of FDI intervention in any country and when macroeconomic variables have been destroyed or not put in place by any nation then it will affect the interest of FDI. The presence of inflation, budget deficit, currency crashes, etc in African countries make the continent less attractive to foreign investors. Recent evidence based on African data suggests that countries with high inflation tend to attract less FDI (Onyeiwu and Shrestha, 2004).

4. Environmental Problem: It is a duty of foreign investors to find nations with better environmental factors and which could enhance their investments. Climatic problem as a result of several harms done to the African environment makes the continent so risky for foreign investments. Findings made it known that in the past, domestic investment policies, for example, on profit repatriation as well as on entry into some sectors of the economy were not conducive to the attraction of FDI (Basu and Srinivasan, 2002).

5. Market Size and GDP Growth-Rate: One of the major factors that make the continent to be termed developing countries' is their low GDP rate annually compare with other regions in the world. The low GDP rate with relative small market size hinders the inflow of FDI in the region. Elbadawi and Mwega (1997) show that economic growth is an important determinant of FDI flows to the region.

6. Poor Infrastructure: This has been a very important topical issue in this research work where infrastructural facilities have been measured in Nigeria compared with the level of interest of the foreign investors looking at the various view of different authors. The relationship between infrastructure and interest of the foreign investors in the country has been discovered contradictory with each other. African countries in general lack proper and adequate infrastructure like telecommunications, transport, power supply, professional labours, etc to facilitate the interest of 
foreign investors in the region. According to Asiedu (2002b) and Morrisset (2000), they provided evidence that good infrastructure has a positive impact on FDI flows to Africa. Onyeiwu and Shrestha (2004) also find no evidence that infrastructure has any impact on FDI flows to Africa.

7. Corruption and Maladministration: Corruption is embedded in Nigerian government and governments of African nations in general. There are no laws designed to eradicate corruption because the leaders who are to make such laws are the backbone behind success of corruption in the region. The government succeeded only in maladministration and this makes security issues to be left without taking proper care of. So foreign investors find it so detrimental to invest in the region where their securities are not certain. Ogundele and Opeifa (2004), describe corruption as consisting of several elements including deceit, trickery, cheating, intentional deception, dishonesty and the conscious premeditated action of a person or group of persons to alter the facts of a matter or transaction for the purpose of selfish personal gains. Bardhan's (1997) definition of corruption as the practice whereby a government official demands bribes from a foreign business in return for the right to operate in a country, industry or location. Wei and Shleifer (2000) found that corruption affects both the volume and the composition of capital inflows into emerging markets negatively because it reduces inward FDI substantially.

\subsection{Structure of the Nigerian Telecommunications Sector}

The telecommunications sector is undergoing very rapid change and explosive growth. Waiting lists for telephone lines have disappeared, while telephone tariffs for local, national and international calls are gradually ranking amongst the lowest in Africa. The liberalization of the sector and the resulting competition by private operators is bringing about very substantial benefits to subscribers in terms of much lower prices and enhanced choice.

Recently, the introduction of mobile telephony to Nigeria in 2001 radically altered the country's communications landscape from a base of $0.73 \%$ teledensity in 2001. The country as of August 2008 had reached $39.45 \%$ teledensity, calculated on the basis of active subscribers. This phenomenal growth was driven by mobile telephony in August 2008. In 2007, the country passed out South Africa as the continent's largest mobile phone market. , Nigeria has 64, 296, 117 active mobile subscriptions as compared to just $1,152,517$ active fixed line subscriptions. Nigeria mobile subscriber's base is projected to rise to 79.8 million by 2010 (NCC 2004 - 2008). Despite this enormous increase, the demand for more lines still persists in Nigeria, though there is a quest not just for lines but also for good quality services from the operators. This strong growth is due mainly to proceedings of the $7^{\text {th }}$ International Conference on Innovation and Management 1892 (Cronin, 1991).

In spite of the extraordinary growth in the sub-sector, quality of services provided, the telecommunications operation has remained unimpressive, owing to poor interconnectivity between the different networks. The problem of constant call droppings, message and call failures and overloaded billings have not been effectively addressed despite numerous complaints from the consuming public, the industry is still plagued with some problems which include poor public power supply; insecurity, such that infrastructure are often vandalized; and high operational cost.

\subsection{FDI and Nigeria Telecommunications Sector}

Globally, economists tend to favour the free flow of capital across national borders because it allows capital to seek out the highest rate of return. Nigeria is reputed to be buoyantly blessed with enormous mineral and human resources but believed to be a high-risk market for investment. Also, decades of bad governance have almost crippled the national economy with corruption and misappropriation of funds becoming the norm rather than the exception. What is the way out of this delirium economic state? Many analysts and experts alike have given thumbs up for foreign direct investment as a veritable booster to kick-start the Nigerian economy. With the enthronement of democratic governance in 1999, the government has taken a number of steps to woo foreign investors into Nigeria. It is thus necessary to assess the in-flow of foreign direct investment finance and its impact on the Nigerian economy.

Positive developments have occurred in Nigeria since May 29, 1999 when democracy replaced the spate of military governments. This has resulted in a number of spirited moves to attract investors local and foreign - into the country. The former President, Olusegun Obasanjo in a bid to achieve this end embarked on a globe trotting mission that saw him interacting with other fellow Presidents and 
the business community of different countries. With a more relaxed taxing system, incentives and the creation of Nigerian Investment Promotion Commission (NIPC), the country was set to lure private sector finance. As a first step, the Government took a bold move to privatise all the ailing public enterprises; Decree No. 25 of July 1996 backs this scheme. The Government set up the Bureau of Public Enterprise (BPE) to oversee this crucial venture and the National Council on Privatization (NCP) headed by the Vice-President to formulate pragmatic policies in this area.

This privatisation drive led to the recent 51 per cent botched share sale of Nigerian Telecommunication Limited (NITEL) to Investors International Limited (IIL) for the sum of USD $\$ 1.317$ billion. However, IIL was only able to come up with 10 per cent of this payment and as penalty for default lost this initial payment. A number of other enterprises have been earmarked for the same process in a bid for government to divest its investment in public service sector. Perhaps the most successful of the Governments bid to attract foreign direct investment finance is the license granted for Global System for Mobile Communication (GSM) to three Service Providers - ECONET WIRELESS, MTN and NITEL - at a handsome sum of USD \$285 million each. This has really boosted the teledensity of the country and their impacts are felt in the employment market, in terms of massive job creation. There have been countless foreign direct investment in-roads into the country, which cut across all sectors - oil and gas industry, capital market, agriculture, solid minerals, and information and communications technology - of the economy.

\subsection{Investment Opportunities in the Sector}

Nigeria is located in the region regarded to have the highest level of international telephone traffic per subscriber. This is estimated at over 200 minutes per year, but the overall level of traffic per inhabitant is less than 1 minute. This suggests that there is a pent-up demand that is not being met by the existing supply of telecommunications services. The business and investment opportunities in the sector are as follows:

1. Huge, Untapped Market: With a population of 160 million people, (majority of who are young teenagers) with improving affordability, the market potential for telecommunications subscriptions and usage over the next few years is indeed very great.

2. Profitability of the Nigerian Telecoms Market: The Nigerian telecommunications market, as it is, is one of the most profitable in Africa, and perhaps, the World. For instance, one of the Nigerian GSM companies declared full profitability less than 18 months after service launch on investments of over US\$700m.

3. Provision of Services: The need to meet up with the ITU standard led to the deregulation of the industry by the Telecommunications law of 1992, which ushered in a new era. Private sector participation and operation in one or more of the deregulated telecommunications undertakings is now allowed. These are:

a. Sales and installation of Terminal Equipment;

b. Provision and operation of Public Pay-phones;

c. Provision and operation of Private Network Links employing cables, radio communications, or satellite, within Nigeria;

d. Provision and operation of Public Mobile Communications (Cellular Mobile telephony, Paging, and Trunked Radio);

e. Provision and operation of Community Telecommunication (Rural and Urban);

f. Provision and operation of Value Added Network/Data Services (Internet, Voice Mail, Electronic Mail services);

g. Repair and maintenance of telecommunications facilities, and

h. Cabling (e.g. Telephone-external and internal wiring for residence, office etc.).

4. Local Manufacture of Equipment: The local manufacture of switching and transmission equipment is necessary to meet the desired expansion. Presently, the country can only boast of local manufacture of low pair capacity cables. Thus, there is the need for the establishment of a plant to manufacture high pair cables as well as fibre optic cables and other telecommunications accessories. 
Other investment opportunities in the industry include investing in any sub-sector of the industry such as manufacture, and supply of equipment and accessories as well as service provision. The industry's size and growth prospects are very high, thus making it a self-sustaining sector. With the deregulation of the industry, private sector participation and operation is fully allowed in the telecommunications undertakings.

However, only corporate bodies registered in Nigeria and/or Nigerian citizens can participate in telecommunications service delivery. Foreign investment is encouraged through Joint Ventures between the foreign investors and their Nigerian affiliates.

\section{RESEARCH Methodology AND SOURCES OF DATA}

The study intends to use econometric approach in estimating the relationship between foreign direct investment in telecommunications and the economic growth of Nigeria. The dependent variable is the contribution of the telecommunications sector to the gross domestic product while the independent variable is foreign direct investment in the telecommunications sector of Nigeria. The Ordinary Least Square (OLS) technique will be employed in obtaining the numerical estimates of the coefficient in different equations using E-view 8.1 output. The OLS method is chosen because it possesses some optimal properties; its computational procedure is fairly simple and it is also an essential component of most other estimation techniques.

A simple linear regression model would be used in the estimation. The model seeks to examine the impact of foreign direct investment in the Telecommunication sector on the performance of the sector in Nigeria. The estimation period is restricted to the period between 1986 and 2014 due to the fact that the country adopted liberalisation policy, which allowed foreign investment in the sector in 1986 under the Structural Adjustment Programme (SAP).

Secondary data is the basis of the data used in this study. They were sourced mainly from the publications of the Central Bank of Nigeria (CBN), namely: CBN Statistical Bulletin, and CBN Annual Report and Statement of Accounts etc. The variables for which data would be sourced include: Foreign Direct Investment in the Telecommunications sector of Nigeria (FDIT), and contribution of the Telecommunications sector to the Gross Domestic Product of Nigeria (GDPT).

\subsection{Theoretical Framework}

Mainstream economists suggest that the Foreign Direct Investment can benefit the real sector of an economy in three broad ways (Parthapratim, 2006). First, the inflow of Foreign Direct Investment can provide a developing country non-debt capital creating source of foreign investment. The developing countries are capital scarce. The advent of foreign investment can supplement domestic saving for improving the investment rate. By providing foreign exchange to the developing countries, Foreign Direct Investment also reduces the pressure of foreign exchange gap for the Less Developed Countries (LDCs), thus making imports of necessary investment goods easy for them. Secondly, it is suggested by mainstream economists that increased inflow of foreign capital increases the allocative efficiency of capital in a country. According to this view, Foreign Direct Investment can induce financial resources to flow from capital-abundant countries, where expected returns are low, to capital-scarce countries, where expected returns are high. The flow of resources into the capital-scarce countries reduces their cost of capital, increases investment, and raises output. However, according to another view, foreign investment does not result in a more efficient allocation of capital, because international capital flows have little or no connection to real economic activity. The third and the most important way Foreign Direct Investment affects the economy is through its various linkage effects via the domestic capital market.

That Foreign Direct Investment is positively correlated with economic growth is situated in growth theory that emphasizes the role of improved technology, efficiency and productivity in promoting growth. The potential contribution of Foreign Direct Investment to growth depends strictly on the circumstances in recipient countries. Certain host country conditions are necessary to facilitate the spillover effects.

The analysis of the effect of Foreign Direct Investment on economic growth in this study is based on the augmented production function in which capital stock, labour and other endogenous factors jointly determine the level of productivity. One of these endogenous factors is Foreign Direct Investment. Foreign Direct Investment is regarded as an endogenous factor because it is attracted largely by the 
high rate of return on investment in developing countries (Ghose, 2004) and the liberalization policy of these countries (Dauda, 2007). Therefore, the model that would be estimated in this study is stated as below:

\subsection{Model Specification}

The main focus of this study is to examine impact of foreign direct investment on sectoral performance in the Nigerian economy with special reference to the Telecommunications Sector. Thus, the model specification is as follow:

GDPT $=f($ FDIT $)$

Mathematical Presentation of the Model

GDPT $=\beta_{0}+\beta_{1}$ FDIT $+\mu$

Where:

GDPT $=$ Contribution of the Telecommunications sector to the Gross

Domestic Product of Nigeria.

FDIT $=$ Foreign Direct Investment in the Telecommunications sector of

Nigeria

$\beta_{0}=$ Intercept of the function (constant term)

$\beta_{1}=$ Regression coefficient

$\mu=$ Stochastic variable.

* Unit Root Test: Test of stationarity aimed at determining whether the variables have dependable means and variances. The Augmented Dickey-Fuller unit-root test was used to test whether the variables are stationary or non-stationary in levels, first or second differencing. Damodar (2005) states that the essence of unit-root test is to allow both the levels and first difference of the relevant variables to enter growth regression and as well as to avoid spurious regression and give accurate results.

* Co-integration Test: Co-integration test is aimed at ascertaining whether there is long-run relationship between the variables. The Johansen co-integration test will be employed to test for the presence of first order auto-correlation and co-integration of variables in the model.

The $\mathrm{R}^{2}$ and adjusted $\mathrm{R}^{2}$ shall be used to measure the degree to which the explanatory variables are responsible for the change in the dependent variable and the goodness of fit as a result of addition of explanatory variables. The F-statistic shall be used to test for the linearity assumption at 5\% level of significance.

* Error Correction Mechanism (ECM): The purpose of error correction model is to indicate the speed of adjustment from the short-run equilibrium to the long-run equilibrium state. The greater the coefficient of the parameter, the higher the speed of adjustment of the model from the short-run to the long-run equilibrium.

\section{DESCRIPTIVE RESULTS}

In the descriptive results, we analyze the time series characteristics of the chosen data during the period of 1986-2014. We had undertaken some econometrics tests on the variables of our model to ascertain their assumptions prior to estimation. Viz: Stationarity, Co-integration tests and Error Correction Model (ECM).

\subsection{Unit Roots Test}

The Augmented Dickey-Fuller (ADF) unit-root test was employed to test for stationarity or the existence of unit roots in the data. The results of the unit-root tests are presented below:

Table1. Augmented Dickey-Fuller (ADF) Test

\begin{tabular}{|l|l|l|l|l|l|}
\hline Variables & \multirow{2}{*}{ ADF-Statistic } & Critical Value & \multicolumn{2}{l}{$\begin{array}{l}\text { Order of } \\
\text { Integration }\end{array}$} \\
\cline { 3 - 6 } & & $1 \%$ & $5 \%$ & $10 \%$ & $1(1)$ \\
\hline GDPT & -5.543084 & -4.356068 & -3.595026 & -3.233456 & $1(1)$ \\
\hline FDIT & -5.184145 & -3.699871 & -2.976263 & -2.627420 & 1 \\
\hline
\end{tabular}

Source: Author's Computation (E-View 8.1 output).

The above empirical test shows that FDIT and GDPT are integrated of order one. They are integrated of the same order; 1(1). From the above table, it it discovered that ADF with trend and intercept are 
integrated of the same order. Considering the ADF test statistics at 5\% and $10 \%$ critical values, it is observed that test statistics are greater than the critical values. Thus, the series are said to be stationary at that first difference.

\subsection{Johansen Co-Integration Test}

A necessary but not sufficient condition for co-integrating test is that each of the variables be integrated of the same order. The Johansen co-integration test uses two statistics tests namely; the trace test and the likelihood eigenvalue test. The first row in each of the table test the hypotheses of no co-integrating relation, the second row test the hypothesis of one co-integrating relation and so on, against the alternative of full rank of co-integration. The results are presented in table 2 below.

Table2. Co-integration for Trace Statistic test

\begin{tabular}{|l|l|l|l|l|}
\hline Hypothesized No. of CE(s) & Eigenvalue & Trace Statistic & Critical Value 0.05 & Prob.** \\
\hline None* & 0.979072 & 141.4607 & 15.49471 & 0.0001 \\
\hline At most $1 *$ & 0.833336 & 44.79442 & 3.841466 & 0.0000 \\
\hline $\begin{array}{l}\text { Trace test indicates 2 co-integrating eqn(s) at the 0.05 level } \\
* \text { denotes rejection of the hypothesis at the 0.05 level }\end{array}$ & \\
$* *$ Mackinnon-Haug-Michelis (1999) p-values
\end{tabular}

Source: Author's Computation (E-view 8.1 Output)

In the model one and two above, the results of the co-integration test are reported here. The tracestatistic value is shown to be greater than the critical values at both $1 \%$ and $5 \%$ levels, thus indicating 2 co-integrating equation at both $1 \%$ and $5 \%$ levels respectively and model three indicating 2 cointegrating equation at both $1 \%$ and $5 \%$ level. The existences of co-integration suggest that there is a long - run relationship between the variables under consideration. Having established co- integration among the variables, we move on to the ECM which will help us to see the short -run dynamics of the model. ECM will enable us determine the speed of adjustment from short - run to long - run equilibrium.

Table3. The Result of Error Correction Model (ECM)

\begin{tabular}{|c|c|c|c|c|}
\hline \multicolumn{5}{|c|}{ Dependent Variable: FDIT } \\
\hline \multicolumn{5}{|c|}{ Method: Least Squares } \\
\hline \multicolumn{5}{|c|}{ Date:01/09/16 Time: $08: 47$} \\
\hline \multicolumn{5}{|c|}{ Sample (adjusted): 19862014} \\
\hline \multicolumn{5}{|c|}{ Included observations 28 after adjustments } \\
\hline Variable & Coefficient & Std. Error & t-statistic & Prob. \\
\hline $\mathrm{C}$ & 895.2989 & 2933.440 & 0.305204 & 0.7627 \\
\hline GDPT & 1.719686 & 0.211206 & 8.142205 & 0.0000 \\
\hline $\mathrm{ECM}(-1)$ & -0.711577 & 0.204926 & -3.472362 & 0.0019 \\
\hline
\end{tabular}

Source: Author's Computation (using E-View 8.1 Output).

\subsection{Interpretation of Regression Results}

From the regression result, it is evident that there is a positive relationship between foreign investment in telecommunications sector of Nigeria and the contribution of the sector to the Gross Domestic Product (GDP) of the country. The observed relationship conforms with the A' Priori expectation. Besides, a change in the explanatory variable, that is, foreign direct investment in telecommunications sector of the Nigerian economy brings about a more proportionate change in the contribution of the telecommunications sector to the Gross Domestic Product (GDP) in the same direction. This signifies the fact that foreign direct investment in the Nigerian Telecommunication sector has impacted positively and significantly on the performance of the sector in terms of its contribution to the growth of the economy.

The standard error of the parameter estimate for foreign direct investment in the Telecommunication sector of Nigeria (2933.440) is less than half of the parameter (447.64945), therefore the null hypothesis would be rejected and the alternative hypothesis would be accepted. This indicates that the parameter estimate is statistically significant in the determination of sectoral performance in Nigeria.

From the percentage points of the t-distribution, the theoretical t-value at 5\% level of significance with twenty-three degree of freedom is 2.05 . Since the critical t-value is less than the calculated tvalue (8.142205), we shall reject the null hypothesis and accept the alternative hypothesis. This means 
that the parameter estimate that foreign direct investment in the Telecommunications sector of Nigeria is statistically different from zero, that is, it is a relevant variable that affects the sectoral performance of the Telecommunications sector of Nigeria to a large extent.

In this model the coefficient of determination gives 0.743572 or $74.4 \%$ approximately. This shows that the regression model is $74.4 \%$ significant. That is, the variation in the contribution of the Telecommunications sector to the Gross Domestic Product of Nigeria is about $74.4 \%$ attributable to the changes in the foreign direct investment in the telecommunication sector of Nigeria.

The calculated F-value (36.24655) is greater than the critical F-value at 5\% level of significance with $\mathrm{v}_{1}=1$ and $\mathrm{v}_{2}=27$ (4.21). We shall therefore reject the null hypothesis and accept the alternative hypothesis. This means that the overall regression or relationship between the foreign direct investment in the Telecommunications sector of Nigeria and contribution of the Telecommunications sector to the Gross Domestic Product of Nigeria is statistically significant and as such, the foreign direct investment in the telecommunications sector of Nigeria is an important factor that determines sectoral performance in Nigeria.

Then Durbin-Watson calculated in this model is 2.422688 , this shows that, there is degree of positive autocorrelation between the foreign direct investment in the telecommunications sector of Nigeria and contribution of the telecommunications sector to the Gross Domestic Product of Nigeria.

The coefficient of error correction mechanism (ECM) is negative. This is in line with economic and econometrics expectations. The error correction mechanism corrects $71 \%$ of the total error that occurs in the model.

\subsection{Impact of Foreign Direct Investment in the Telecommunications Sector of the Nigerian Economy}

On assumption of office in May 1999, the Olusegun Obasanjo administration swung into action to make a reality the complete deregulation of the telecommunications sector, most especially the much touted granting of license to GSM service providers. The government also put in motion the privatization of NITEL. This proactive approach by the government and the telecommunication sector had made it possible for over 87million Nigerians to clutch GSM phones today (CBN, 2010).

Since the liberalisation of the telecommunications industry in 2001, capital investments in mobile networks and operations have constituted 80 per cent of overall investment going into the telecommunications sector - a total of more than $\$ 12 \mathrm{bn}$ by the middle of 2008 . Total figure for the industry, as of March 2010, according to the Nigerian Communications Commission (NCC), reached $\$ 18 \mathrm{bn}$, of which $\$ 16 \mathrm{bn}$ is related to mobile.

There have been significant increases in the level of foreign direct investment in the Nigerian telecommunications industry, especially since 1999. From a mere US\$ 50 million at the end of 1999 , total private investment in the sector rose to about US\$2.1 billion by the end of 2002, out of which about $75 \%$ was attributable to mobile networks. At the end of 2003, total industry investment was estimated at about US\$3.8 billion. The industry investment was estimated at about $\$ 18$ billion in 2009 (CBN, 2010).

Since 1999, Nigeria has demonstrated the highest potential for ICT investment in Africa; the NCC reported 64 million SIMs in operation at the beginning of January 2009, with 23 million new subscribers signing up in 2008. This growth of 55\% in 2008 alone has encouraged a flurry of local and multinational investors into the industry. In 2007, Telecommunications attracted the most private participant investment in Africa (86\% of total). Nigeria claimed the dominant share of the $\$ 9.5$ billion (reportedly the highest since 1990) at 28\% (\$2.66 billion) followed by South Africa at 11\% (\$1.045 billion).

Deregulation of the Nigerian Telecommunications system in 2001 gave way to private involvement which in turn led to emergence of major players in the field - both local and foreign companies. These include MTN, Zain, Etisalat, Globacom, Mtel, Multilinks, Reltel and Visaphone. These providers offer telecommunications services in the area of telephony service, Global System of Mobile Communication Services (GSM), fixed wireless access and VSAT.

The explosion of the telecommunications sub-sector of Nigeria propelled by foreign investment, has seen significant contribution to the growth and development of Nigerian economy. The banking and finance sector is reaping the benefits of deregulation as the telecommunications sector is creating more opportunities for investment. VSAT companies offering satellite-based services have also become operational, providing support for online banking and funds transfer services in the country. 
The level of investment in the country due to telecommunications liberalisation is currently valued at about $\$ 18$ billion. This is expected to rise with more operators coming on stream.

Foreign investments in the telecommunications sub-sector have also contributed to the creation of jobs in the economy. Employment opportunities created in the country as a result of telecommunications liberalisation is estimated to be in excess of 8,000 jobs. However, for a sub-sector that has been in the limelight of the national economy in the past ten years, 8,000 jobs seems to be paltry given the growing number of educated youths that needs jobs. The truth is that the sub-sector is technology-driven and as such cannot be expected to create enormous job openings.

The GSM Service Providers have completely changed the tempo of the Nigerian business terrain by creating countless opportunities for small and medium businesses in franchise, dealerships, and retailer ships, street re- charge/refill card hawkers, to individuals selling second-hand handsets, accessories and value added services within the GSM market. It has employment explosion both directly and indirectly. Over 87 million Nigerians now have a convenient way of communication. This development has greatly affected positively the business environment. MTN for instance, appointed over 350 dealers nationwide. GSM has actually created the habit of time management in Nigerians.

GSM contributed to the reduction of motor accidents on major Nigerian highways due to the elimination of long journeys for pleasure and business. It is now convenient to place a call to business associates rather than waste valuable time embarking on sometimes, needless journeys. It has also improved internet and information technology awareness through WAP (Wireless Application Protocol) Services, E-commerce through Mobile Payment Systems called M-Payments among others.

The contribution of foreign direct investment in the telecommunications sub-sector of Nigeria to her economic growth and development can best be captured by the figures below:

Table1. Trend of Foreign Direct Investment in Telecommunication Sector and the Contribution of the Telecommunications Sector to the Gross Domestic Product of Nigeria (1986 - 2014)

\begin{tabular}{|c|c|c|}
\hline Year & $\begin{array}{l}\text { Contribution of the Telecommunications Sector to the } \\
\text { Gross Domestic Product of Nigeria (N'm) }\end{array}$ & $\begin{array}{lcc}\text { Foreign Direct } \quad \text { Investment } & \text { in } \\
\text { Telecommunications Sector (N'm) } & \\
\end{array}$ \\
\hline 1986 & 129.40 & 80.40 \\
\hline 1987 & 130.70 & 75.60 \\
\hline 1988 & 131.90 & 160.60 \\
\hline 1989 & 134.60 & 158.20 \\
\hline 1990 & 137.30 & 240.50 \\
\hline 1991 & 140.00 & 373.20 \\
\hline 1992 & 144.90 & 391.50 \\
\hline 1993 & 150.00 & 426.40 \\
\hline 1994 & 151.50 & 429.60 \\
\hline 1995 & 159.10 & 374.80 \\
\hline 1996 & 167.00 & 485.60 \\
\hline 1997 & 177.00 & 672.60 \\
\hline 1998 & 185.90 & 689.20 \\
\hline 1999 & 195.50 & 820.30 \\
\hline 2000 & 207.50 & 820.30 \\
\hline 2001 & 2398.68 & 955.30 \\
\hline 2002 & 2983.07 & 1736.30 \\
\hline 2003 & 3785.47 & 2890.50 \\
\hline 2004 & 6015.91 & 4281.10 \\
\hline 2005 & 7851.66 & 5565.40 \\
\hline 2006 & 10567.90 & 8291.00 \\
\hline 2007 & 14226.75 & 10758.20 \\
\hline 2008 & 19159.16 & 7996.80 \\
\hline 2009 & 25812.44 & 13238.10 \\
\hline 2010 & 35674.18 & 72073.30 \\
\hline 2011 & 291712.09 & 7564.4 \\
\hline 2012 & 331502.79 & 6519.6 \\
\hline 2013 & 6621734.16 & 85606.6 \\
\hline 2014 & 5420654.36 & 8506.4 \\
\hline
\end{tabular}

Source: Central Bank of Nigeria Statistical Bulletin; Central Bank of Nigeria Annual Report and Statement of Accounts for various years 
Table above shows the trend of Foreign Direct Investment in Telecommunications Sector and the contribution of the Telecommunications Sector to the Gross Domestic Product of Nigeria between 1986 and 2014. A glance at the table would reveal that the Foreign Direct Investment in Telecommunications Sector increased in most of the years reviewed with occasional decrease recorded in few years. On the other hand the contribution of the Telecommunications Sector to the Gross Domestic Product of Nigeria increased throughout the years. Just as it was revealed by the regression result, the Foreign Direct Investment in Telecommunications Sector and the Contribution of the Telecommunications Sector to the Gross Domestic Product of Nigeria have positive relationship during the years considered.

A major striking observation in the trend is that the contribution of the Telecommunications Sector to the Gross Domestic Product of Nigeria increased astronomically from $\$ 207.5$ million in 2000 to \#2398.68 million in 2001. Besides, the telecommunications sector contributed significantly to the Gross Domestic Product of Nigeria between 2001 and 2010 than what was recorded between 1986 and 2000. The reason for this is not far-fetched. It is as a result of the full deregulation of the telecommunications sector in 2001 by the Obasanjo administration which attracted huge inflow of foreign investment into the industry. It is evident from the foregoing that the country has profited immensely from Foreign Direct Investment especially through the deregulation of the telecommunications sector.

\section{CONCLUSION AND RECOMMENDATIONS}

According to a recent World Bank report, foreign direct investments in Sub-Saharan Africa yielded the highest returns in the World in 2002. US companies that invested in Africa between 1990 and 2002 , according to UNCTAD, had average annual returns of 25 percent compared with a world average of 12 percent. Their Japanese counterparts made three times more profit on their African investments than elsewhere. Net income from British direct investment in Sub Saharan Africa (excluding Nigeria) increased by 60 percent between 1985 and 1995. The overwhelming evidence shows that Africa is the fastest growing emerging market, particularly in Information and Communication Technologies (ICTs), and especially in mobile communications. Recent large investments are generating significant multiplier effects for African economies through the transfer of technology (the generation of employment), improved productivity, and the fulfillment of demand for services. Examples of successful ICT investments abound in every region on the continent.

Despite impressive returns on investment throughout the continent, getting finance for growth and expansion from developed economies is often impossible, as many local entrepreneurs and businesses can testify. "Most of Africa is effectively starting from scratch when it comes to (ICTs)," says Sicelo Sikakne, Senior Account Manager at Techno Industries, "so very large sums are needed that go well beyond the capacity of most local institutions." MTN Nigeria's announcement in late 2003 of a package of syndicated loans, equity, and debt totaling US\$395 million from over 20 local and international financial institutions is a case in point. This MTN investment is one of IFC's largest in the telecommunications sector and its second largest investment to date in Sub-Saharan Africa. It is also the biggest inflow of funds into ICT in Africa in recent times.

Countries that can offer a large domestic market and/or natural resources have inevitably attracted foreign investors in Africa. South Africa, Nigeria, Ivory Cost, and Angola have been traditionally the main recipients of foreign direct investment within the region.

Over the past few years, Nigeria has attempted to improve its business climate in an effort to attract more foreign companies. Establishing a competitive business climate is a difficult task because it takes time not only to implement policies but also to convince potential investors. In the case of Nigeria, it is even more difficult because the country is not even on the radar screen of most companies. It is a fact that countries that are perceived as most attractive investment environments attract substantial foreign direct investment inflows, more than countries that have bigger local market and/or natural resources.

To improve the climate for foreign direct investment, strong economic growth and aggressive trade liberalization can be used to fuel the interest of foreign investors. Similarly, a closer look at the experience of countries that have shown a spectacular improvement in their business climate reveals that the implementation of a few visible actions is essential in the strategy of attracting foreign direct investment. Beyond macroeconomic and political stability, Nigeria should focus on a few strategic actions such as: 
a. Opening the economy through a trade liberalization reform;

b. Modernizing mining investment codes;

c. Adopting international agreements related to FDI;

d. Developing a few priority projects that have a multiplier effects on other investment projects; and

e. Mounting an image building effort with the participation of high political figures, including the President.

Based on the findings of this study, the following recommendations are thereby suggested in order for Nigeria to attract more foreign direct investment in the Telecommunications sector and harness its benefits better.

1. Since the regression analysis revealed that Foreign Direct Investment in the Telecommunication sector impact positively and significantly on the performance of the sector, the government should initiate policies that will promote the long-rum growth of the Telecommunication sector and the economy at large. This will go a long way in attracting long-term fund that will be available for productive purposes.

2. A stable political environment was found to be fundamental in attracting foreign investment to an economy. Therefore, the government should focus on maintaining political stability before formulating favourable policies that will attract long-term funds into the country.

3. The government must create a conducive business environment by improving its infrastructural facilities assuring security of life and property and maintains policy consistency in order to boost local investment in the country. It should also set machinery in motion to improve the quality of the labour force through improved educational system, and qualitative and continuous manpower training.

4. The capital market should be further deepened through the introduction of derivatives as stock index future, interest and currency future as well as options on individual stock. Furthermore, the regulators of the capital market must continue to strengthen the transparency of the market through effective oversight, professionalism and improved operational facilities so as to boost the confidence of both local and foreign investors in the market.

5. Since the exchange rate is also a significant determinants of Foreign Direct Investment, the government must endeavour to stabilize the exchange rate so that investible funds will be cheap and yield high returns in the country especially to foreign investors.

\section{REFERENCES}

Adam, Z. (2002). Fine-tuning foreign investment: Differentiating FDI and portfolio investment in post-communist East Central Europe, Paper presented at the Second EPIC Workshop in Florence, May 16-22.

Alfaro, L., A. Chanda, S. Kalemli-Ozcan and S. Sayek (2006). How Does Foreign Direct Investment Promote Economic Growth? Exploring the Effects of Financial Markets on Linkages, NBER Working Paper 12522.

Alfaro L. and Chanda A. (2003). FDI and Economic Growth: The Role of Local Financial Markets. Journal of International Economics, February.

Anyanwu, J.C. (1993). Monetary Economics: Theory Policy and Institution. Onitsha: Hybrid Publishers Ltd.

Aremu, J.A. (2005). Attracting and Negotiating Foreign Direct Investment with Transnational Corporations in Nigeria. Lagos, Nigeria: Market Link Communications.

Asiedu, E. (2002b). Aggressive Trade Reform and Infrastructure Development: A Solution to Africa's Foreign Direct Investment Woes, University of Kansas, Kansas, Mimeo.

Asideu E (2002). On the Determinants of Foreign Direct Investment to Developing Countries: Is Africa Different? World Development30 (1) 107-119.

Barro, R. J. (1991). Economic Growth in a Cross Section of Countries. Quarterly Journal of Economics.106 (2), 407 -443. 
Basu, A. and Srinivasan, K. (2002). Foreign direct investment in Africa: Some case studies, IMF Working Paper 02/61, IMF, Washington, DC.

Bjorvatn, K. (1999). “Third world regional integration”, European Economic $\quad$ Review, 43, 1, pp. 47-64.

Busse, M. and Hefeker, C. (2005). Political Risk, Institutions and Foreign Direct Investmen”. HWWA Discussion Paper, No. 315, April.

Dauda R. O. S. (2007). The impact of FDI on Nigeria's Economic Growth: Trade Policy Matters. Journal of Business and Policy Research, Vol. 3, No.2, pp.11-26.

Elbadawi, I. and Mwega, F. (1997). Regional Integration, Trade, and Foreign Direct Investment in Sub-Saharan Africa, in: Iqbal, Z. and Khan, M. (eds), Trade Reform and Regional Integration in Africa, IMF, Washington DC.

Fosu, O. E. and Magnus, F. J. (2006). Bounds Testing Approach to Cointegration: An Examination of Foreign Direct Investment, Trade and Growth Relationships, American Journal of Applied Sciences, Vol. 3, No. 11, pp. 2079-2085.

Ghose, A. K. (2004). Capital inflows and investment in developing countrie. Employment Strategy Papers, No. 2004/11.

Helpman, G.H.E. (1991). Innovation and Growth in the Global Economy. Cambridge: MIT Press.

Knill, A. M. (2005). Can Foreign Portfolio Investment Bridge the Small Firm Financing Gap around the World? World Bank Policy Research Working Paper, No. 3796, December.

Morisset, J. (2000). Foreign Direct Investment in Africa: Policies Also Matter, Transnational Corporations, 9 (2), pp. 107-25.

Ngowi, H. (2001). Can Africa increase its global share of foreign direct investment. West Africa Review, Vol. 2, No. 2.

Obsanjo, O. (2001). State of African Economy. An address to the US Chamber of Commerce, Washington DC, May 14.

Ogundele, O.J.K and Opeifa, A.Z. (2004). Spiritual Capitalism: Holistic Approach for Successful Implementation of NEEDS, NEEDS Research Unit Conference Department of Economics, University of Lagos, Akoka, 23rd- 24thSeptember.

Omisakin, O., Adeniyi, O. and Omojolaibi, A. (2009). Foreign Direct Investment, Trade Openness and Growth in Nigeria. Journal of Economic Theory, Vol. 3, No. 2, pp. 13-18.

Onyeiwu, S. and Shrestha, H. (2004). Determinants of Foreign Direct Investment in Africa, Journal of Developing Societies, 20 (1-2), 89-106.

Parthapratim, P. (2006). Foreign Portfolio Investment, Stock Market and Economic Development: A Case Study of India. A paper submitted for the Annual Conference on Development and Change Mission: Promoting Development in a Globalized World, Sao Paulo, Brazil, November 18 - 20.

Rogoff, K. and Reinhart, C. (2003). FD1 to Africa: The Role of Price Stability and Currency Instability, Working Paper 03/10, International Monetary Fund.

Romer, P. (1990). Endogenous technological change. Journal of Political $\quad$ Economy, 98(5),71103.

Umah, K.E. (2007), The Impact of Foreign Private Investment on Economic Development of Nigeria, Nigeria. Journal of Economics and Financial research. Vol. 1, No.3.

UNCTAD (1999). World Investment Report: Foreign Direct Investment and the challenge of investment.

UNCTAD (2005). Economic Development in Africa: Rethinking the Role of Foreign Direct Investment. United Nations Publication, New York and Geneva.

Vita, G. D. and Kyaw, K. S. (2008). Determinants of FDI and Portfolio Flows to Developing Countries: A Panel Cointegration Analysis. European Journal of Economics, Finance and Administrative Sciences, Issue 13.

Wei, SJ, Shleifer, A. (2000). Local corruption and Global Capital Flows. Brookings $\quad$ Paper on Economic Activity (2): 303-354. 
AUTHOR'S BIOGRAPHY

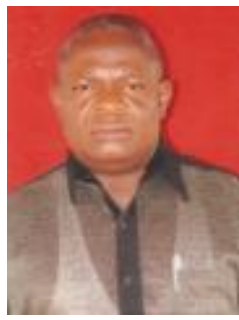

Dr. Ezeanyeji Clement Ifebuolili, is a senior lecturer in the Department of Economics, Faculty of Social Sciences, Chukwuemeka Odumegwu Ojukwu University (COOU). He hails from Isi-Achina in Aguata Local Government Area of Anambra State, Nigeria.

Dr. Ezeanyeji obtained his BA, Economics from Karnatak University Dharwad, Karnataka State. MA, Economics from the prestigious Sir Venketeswara University, Tirupathi in Andesh State, and his Doctorate (Ph.D) degree from Shivaji University, Kolhapur Maharashtra State, all in India. He also obtained his Post Graduate Diploma in Business Administration, from Annamalai University, Annamalai Nagar, Tamil Nadu State, and a Post Graduate Diploma in Personnel Management and Industrial Relations from Indian Institute of Management and Industrial Relations, Nehru Nagar, Agra, Uttar Pradesh State, all in India as well.

The author's teaching and research experiences are in the field of Monetary Economics, Public Finance, Industrial Economics, Taxation and Fiscal Policy, and Labour Economics as well as Economics of Production. He has drawn from his teaching experiences in his various publications.

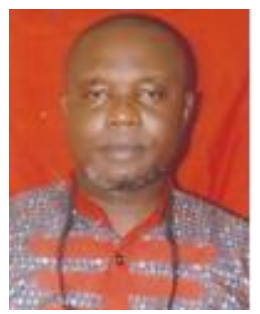

Lord'nuel Ogo Ifebi, is a lecturer in the Department of Economics, Faculty of Social Sciences, Chukwuemeka Odumegwu Ojukwu University (COOU). He hails from Okofia Otolo Nnewi, Anambra State, Nigeria. He is married with children.

Lord'nuel Ogo Ifebi obtained his B.Sc Economics from Unizik, Anambra State and currently doing his Doctorate (Ph.D) degree in Ebony State University, Abakaliki. 